\title{
LEKRA and ensembles \\ Tracing the Indonesian musical stage
}

\author{
Rhoma Dwi Aria Yuliantri
}

The ceremonial reading of the proclamation of Independence on 17 August 1945 signaled a new era for Indonesia. This ceremony without precedent occurred together with the raising of the Red and White flag, and the singing of the anthem 'Indonesia Raya'. ${ }^{1}$

The proclamation of independence signalled the search for characteristics of a national culture. The birth of 'Indonesia' is inseparable from politico-diplomatic struggle, physical revolution, and cultural revolution. Cultural revolution within the field of music was marked by the birth of the poetry of struggle and nationalist propaganda. Music that was 'politically conscious' and that contained 'propagandistic' nuances was already familiar in Indonesia, with roots dating to the Japanese Occupation. In 1943, for example, Japan established the Keimin Bunka Shidoso (Cultural Centre) in Jakarta, and instructed artists to support the war efforts of Dai Nippon by creating propaganda songs (Eritha Rohana Sitorus 2009:40-2; Aiko Kurasawa 1993:229-59). In addition to carrying out their 'formal mission' for the Japanese government, artists also created works for the independence movement. One example is the composer Cornel Simanjuntak who is well known for his patriotic songs..$^{2}$ In the 1945-1966 era, the air was thick with music conscious about politics, nation, political parties, the people, the revolutionary struggle and diplomatic language.

1 See Pramoedya Ananta Toer et al. 1999:18. The song 'Indonesia Raya' is a march composed by Wage Rudolf Supratman (W.R. Supratman). It was first sung at the Youth Congress on 28 October 1928, and later adopted as the Indonesia's national anthem even though it had since undergone changes both in its lyrics and melody. See further Rudolf Mrázek 1994:45.

2 Manik 1952. Cornel Simanjuntak was born in 1921 in Pematang Siantar, North Sumatra, and died in Yogyakarta in 1946. In 1945-1946 he joined the armed struggle against the Allies. Several of his compositions are still remembered, for example: Tanah tumpah darah (Land for which we shed our blood), Maju tak gentar (Advance, unflinching), Citra mekar melati (Image of the blossoming jasmine), O angin, kupinta lagi (Oh, wind, I ask once more), Pada pahlawan (To the heroes), Teguh kukuh berlapis baja (Firm and strong, wrapped in steel), Indonesia tetap merdeka (Indonesia free forever), Sorak sorak gembira (Cheer, cheer joyously). 
This focus of this essay will be a discussion about the dynamics of the Indonesian music promoted by the Lembaga Kebudajaan Rakjat (LEKRA, the Institute of People's Culture) in the late 1950s and early 1960s, together with the activity of the music and dance ensembles that flourished on the stage of Indonesian culture during the Soekarno era.

LEKRA's activities, especially in the fields of literature and art, have been the subject of much writing. This essay is a modest effort to approach and study the music that LEKRA and the choral ensembles gave voice to, and draws upon written sources, especially the newspaper Harian Rakjat ${ }^{3}$ supplemented with other supporting written sources such as Mimbar Indonesia, ${ }^{4}$ and oral sources (interviews with several musicians of the 1950-1965 period, especially from the early 1960s). The communist daily newspaper Harian Rakjat is the primary source I draw on because of the lack of data available on this topic. Of course, given that Harian Rakjat is the chief source, the role of LEKRA in the field of music will appear rather large. To obtain a more balanced picture, a study using a more comprehensive and complete set of sources will be necessary.

\section{LEKRA AND THE REVOLUTIONARY PATH OF INDONESIAN MUSIC}

After the August 1945 revolution, Indonesia was searching for a national cultural identity. In the course of this search, the cultural organization called LEKRA emerged, its founding proclaimed by D.N. Aidit, M.S. Ashar, A.S. Dharta, and Njoto on 17 August $1950 .{ }^{5}$ LEKRA was intended as an organization that would gather

3 Harian Rakjat (HR), the Indonesian Communist Party's (PKI) newspaper, provided space for LEKRA's artists to discuss cultural matters. HR was first published on 31 January 1951 under the name Suara Rakjat. One of the members of the editorial board was Njoto, who was also one of LEKRA's founders.

4 Mimbar Indonesia (MI) was a magazine that was first published in 1947 and continued publication until 1966. For a detailed discussion on Mimbar Indonesia, see Els Bogaerts in this volume.

5 'Laporan umum pengurus pusat LEKRA kepada Kongress Nasional ke I LEKRA', Harian Rakjat, 31-1-1959. See further Keith Foulcher (1986:20) who lists the six members of the initial LEKRA Secretariat: A.S. Dharta, M.S. Ashar, Herman Ardjuno, Henk Ngantung, Njoto and Joebaar Ajoeb. A.S. (Adhi Sidharta) Dharta (1924-2007), a writer who also wrote under many pseudonyms including Klara Akustia and Jogaswara, was LEKRA's first General Secretary until 1959. After the 1965 coup, he was imprisoned from 1965-1978. Njoto (1927-1965), a musician and writer, was elected to the Communist Party's five-member polit bureau in 1951 but was fired from his position as its Deputy Head II in 1964. He disappeared, presumed murdered, in 1965. The artist Henk Ngantung (1921-1991), held administrative positions within LEKRA and was Governor of Jakarta in 1964. He escaped imprisonment after 1965. 
and strengthen the ties of national culture and strongly support the Revolution. As stipulated in LEKRA's Mukadimah (Preamble, 1950): 'The failure of the August 1945 Revolution meant also the failure of the struggle by cultural workers to destroy the colonial culture and replace it with a democratic culture, a People's culture' ${ }^{6}$ This stance became even clearer when LEKRA's Secretary General Joebaar Ajoeb ${ }^{7}$ delivered the general report of the Central Secretariat of the organization before the participants of LEKRA's first National Congress in Solo in 1959:

Lekra was founded in 1950 due to an awareness of the essence of the August 1945 Revolution and of the connection between the Revolution and culture. An awareness that the Revolution has great significance for culture and, at the same time, on the other hand, culture has great significance for the August Revolution. ${ }^{8}$

From the outset, LEKRA affirmed its nature as an open organization in the sense of being open to any artistic trend, and to working with any cultural organization with a similar ideology. ${ }^{9}$ This was explained in LEKRA's Mukadimah (1950):

The attitude of a People's Culture to foreign cultures is in no way one of enmity. The essence of progressive foreign cultures will be drawn on as much as possible in furthering the development of an

6 Foulcher 1986:213. 'Gagalnya Revolusi Agustus 1945 berarti juga gagalnya perjuangan pekerja kebudayaan untuk menghancurkan kebudayaan kolonial dan menggantikannya dengan kebudayaan yang demokratis, dengan kebudayaan Rakyat' (Foulcher 1986:209) (modern spelling as in Foulcher).

7 Joebaar Ajoeb was born in 1926 in Bukit Tinggi, West Sumatra, and died in Bandung in 1996. In 1959 President Soekarno appointed him as a member of the DPR-GR/MPRS RI (parliament). He was elected Secretary General of LEKRA at its first plenary session on 28 January 1959 in Solo, Central Java. Prior to 1959, Ajoeb had been a member of the Youth Review Board of the Department of Education and Culture, a member of the Radio Broadcast Advisory Board of the Department of Information of Indonesia, and a member of the Film Board of the Department of Information. To date I have been unable to find information about the exact periods of Joebaar Ajoeb's involvement with these institutions. Following the coup in 1965, Ajoeb was arrested and imprisoned without trial.

8 'LEKRA didirikan ditahun 1950 dari kesadaran tentang hakekat Revolusi Agustus 1945 dan tentang hubungannja antara Revolusi itu dengan kebudajaan. Bahwa Revolusi itu besar sekali artinja bagi kebudajaan, dan bahwa sekaligus, sebaliknja, kebudajaan besar sekali artinja bagi Revolusi Agustus' (Harian Rakjat, 31-1-1959).

9 Sabar Anantaguna (b. 1929), one of the members of LEKRA's Central Secretariat (following the National Congress of 24-29 January 1959), explained the open character of LEKRA as an organization (interview 4-9-2009). Anantaguna, a former classmate of Njoto in their hometown of Jember, East Java, was arrested after the 1965 coup and imprisoned on Buru Island from $1970-1978$. 
Indonesian people's culture. However, in drawing on that essence we will not slavishly copy anything. ${ }^{10}$

LEKRA placed the people as the root of creativity, as was mirrored in its conception of People's culture in 1950. According to LEKRA's Mukadimah, 'The struggle of a People's Culture is an inseparable part of the struggle of the People in general.'11

Organizationally, LEKRA was divided into seven creative institutes; ${ }^{12}$ four of them were formed after the 1959 LEKRA Congress in Solo: The Lembaga Sastera Indonesia (Indonesian Literary Institute), the Lembaga Senirupa Indonesia (Indonesian Fine Arts Institute), the Lembaga Film Indonesia (Indonesian Film Institute), and the Lembaga Senidrama Indonesia (Indonesian Dramatic Art Institute). The other three creative institutes, namely the Lembaga Musik Indonesia (LMI, Indonesian Music Institute), the Lembaga Senitari Indonesia (Indonesian Dance Art Institute), and the Lembaga Ilmu Indonesia (Indonesian Institute of Science) were all formed following LEKRA's plenary meeting of August 1960. ${ }^{13}$

The focus of LMI's attention included local Indonesian music as well as Western music (diatonic), and traditional music as well as new compositions, especially those with what was considered a revolutionary focus. The cultural tasks that LEKRA took on within the field of music were set out in the findings of LEKRA's 1959 National Congress in Solo. They were to:

1. Organize the registration of People's music [-dance] in all regions.

2. Spread and intensify music education [and dance] through:

10 Foulcher 1986:217. Sikap kebudayaan Rakyat terhadap Kebudayaan asing atau luar Negeri sama sekali tidak bersikap permusuhan. Kebudayaan Asing yang progressif akan diambil sarinya sebanyak-banyaknya untuk kemajuan perkembangan gerakan kebudayaan rakyat Indonesia. Tetapi dalam hal mengambil sari ini, kita tidak akan menjiplak secara membudak (Foulcher 1986:212) (The capital letters follow the original text, but Foulcher reproduced with modernized Indonesian spelling).

11 'Perjuangan Kebudayaan Rakyat adalah bagian yang tidak dapat dipisahkan dari perjuangan Rakyat umum' (Foulcher 1986:211).

12 In Rhoma D.A. Yuliantri and Muhidin M. Dahlan (2008:35-38), LEKRA is described as having only 6 creative institutes, without mentioning the Indonesian Science Institute. To date, I have not found further information concerning The Indonesian Science Institute.

13 It is not known with certainty when the LMI was formed as a separate entity from the Dance Art Institute. In LEKRA's 1st Congress in Solo in 1959, these two institutes were mentioned jointly as 'The Indonesian Institute of Music and Dance' (Lembaga Musik Indonesia dan Lembaga Tari Indonesia). See Laporan Kebudajaan Rakjat II (People's Culture Report II), published by LEKRA's publishing section, p. 165. LMI Djogja was founded later, on 15 April 1963. See 'Laporan Kusni Sulang melawan musik ngak-ngik-ngok mengembangkan musik jang kerakjatan', Harian Rakjat, 2-1-1964. 
a. Publications and broadcasts;

b. Seminars and discussion circles;

c. Competitions and performances.

3. Encourage the prevention and elimination of indecency and other symptoms of decadence in music [and dance].

4. Fight for the intensification of music [and dance] lessons in schools, especially in teacher-training schools.

5. Organize music [and dance] exchanges both between regions and internationally.

6. Encourage selectivity and creative work in the field of music [and dance].

7. Call to attention the rediscovery, development, and improvement of People's music [and dance] along with their instruments. ${ }^{14}$

At first, LMI intended to set up registration and development programs for regional musics. Five years later, in 1964, in step with the changes in Soekarno's political stance given the increasing influence of the Left at a national level, the musical agenda changed as well. LMI's activities were increasingly tied to political activities. This also served to confirm LEKRA's stand in the field of culture, that is, 'politics as the commander'.

LMI's first National Conference took place from 31 September-5 October 1964 in Jakarta. According to the report in Harian Rakjat, the aim of the conference was to oppose music regarded as 'crazy' (kegila-gilaan), and to carry out Bung Karno's line in the field of music. ${ }^{15}$ This national conference took place as the cultural situation was at the boiling point of change, or, as President Soekarno put it, 'Tahun vivere pericoloso' (abbreviated as the acronym Tavip) or 'The year of living dangerously'. As the conference proceeded, Sudharnoto, the Chair of LMI, discussed in his report the issue of Indonesian music in the midst of the heating political situation. In his view, music functioned to cultivate national culture and oppose

14 1. Menjelenggarakan registrasi music [-tari] Rakjat diseluruh daerah. 2. Meluaskan dan mengintensifkan pendidikan musik [dan tari] dengan djalan: a. Penerbitan dan penjiaran; $b$. Seminar-seminar dan lingkaran-lingkaran diskusi; c. Perlombaan dan pertundjukan. 3. Menggiatkan pentjegahan dan pemberantasan pentjabulan serta gedjala-gedjala dekaden lainnja dalam musik [dan tari]. 4. Memperdjuangkan pengintensifan peladjaran musik [dan tari] disekolah-sekolah, terutama disekolah-sekolah guru. 5. Menjelenggarakan tukar-menukar musik [dan tari], baik antardaerah maupun antarnegara. 6. Menggiatkan kerdja seleksi dan kreasi dilapangan musik [dan tari]. 7. Mengingatkan kerdja penggalian, pengembangan dan peningkatan musik [dan tari] Rakjat serta alat-alatnja. See 'Resolusi atas laporan musik dan laporan tari' dalam Kongres Nasional ke-I LEKRA', Harian Rakjat, 14-2-1959.

15 'Konferensi I Lembaga Musik Indonesia untuk melaksanakan garis Bung Karno dibidang musik', Harian Rakjat, 25-10-1964. 
a US culture regarded as imperialistic. Using the prevalent slogans of the time, Sudharnoto outlined his view:

[...] with the rhythm of Djarek [Djalannja Revolusi Kita or The Path of Our Revolution], Resopim [Revolusi, Sosialisme, dan Pimipinan or Revolution, Socialism, and Leadership], with the Takem [Tahun Kemenangan or Year of Victory] and Gesuri [Genta Suara Revolusi Indonesia or The Pealing Bell of the Indonesian Revolution] melody, with the harmony of Manipol [Manifesto Politik] strengthened by the glorious arrangement of Tavip, progressive music artists will smash American imperialist culture, smash Manikebu [Manifes Kebudayaan or Cultural Manifesto] and cultivate a music with national identity. ${ }^{16}$

RAISING THE PROFILE OF REGIONAL MUSIC

Discussions about people's music were prominent in the early 1960s (Wienkatoe 1960). In this case, 'people's music' referred to regional music within the framework of the search for national identity thought to have its 'own identity', and in conformity with Soekarno's slogans about promoting 'national identity' ('kepribadian nasional). LMI's first national conference in 1964 ceremoniously announced its idea to research and compile data on regional music and songs down to the most isolated islands. ${ }^{17}$ LEKRA strove to make regional music not merely marginal or tokenistic, but to be pushed into the centre of things while raising its standards as high as possible.

From the early 1950 s, attention to 'national music' became one element in the search for a national culture thought to mirror Indonesian identity. LEKRA was highly involved in this effort, both as an institution and at the level of its individual members, working together with the government. One example of government activity in regional music involving members of LEKRA was the survey of people's entertainment, including music. In 1954, for example, five years before LMI was established, the composer Amir

16 [d] engan irama Djarek, Resopim, dengan melodi Takem dan Gesuri, dengan harmoni Manipol yang diperkuat gubahan megah Tavip, seniman musik progresif mengganjang kebudajaan imperialisme Amerika Serikat, mengganjang Manikebu, dan membina musik jang berkepribadian nasional. 'Laporan Umum Sudharnoto "Betapa besar bahaja musik dekaden”, Harian Rakjat, 2-11-1964.

17 See 'Pokok-pokok laporan Ketua Umum Konfernas LMI', Harian Rakjat, 15-11-1964. 
Pasaribu $^{18}$ and the writer Pramoedya Ananta Toer, ${ }^{19}$ together with LEKRA members like poet and writer Rivai Apin, ${ }^{20}$ cultural figure Joebaar Ajoeb, and painter Basuki Resobowo, ${ }^{21}$ received a mandate from the Jakarta municipal government to undertake observations of people's entertainment including gambus, keroncong, dagelan, topeng, reog, bobodoran, and lenong in Kampung Bojong, Lenteng Agung, a hamlet of the Pasar Minggu area in Jakarta. ${ }^{22}$

To what extent was the goal of the observations of regional arts undertaken by LMI similar to that of the government? In-depth research would be required to answer that question, but Wienaktoe's writing can give us some idea. Wienaktoe was an official in the Departemen Pendidikan, Pengadjaran dan Kebudajaan (DPPK, Department of Education, Teaching, and Culture) in 1960. He explains that one aim of the revitalization of people's music was to research the origins of music, the original conditions under which the music was sung, the mood that it created, and the rhythms sung by the people, and not just to note down the melody of regional music and then add interesting words or music. ${ }^{23}$ However, the revi-

18 Amir Pasaribu (1915-2010) was born in Siborong-borong, North Sumatra, and died in Medan. He was trained as a classical musician. He also founded the Composer's League and The Indonesian Music Association (1950) (Eritha Rohana Sitorus 2009:13-72). Regarding the extent of his relations with LEKRA, I have not yet been able to locate comprehensive data. During the years after the coup when anyone suspected to have leftist connections was being hunted, Pasaribu moved to Suriname where he taught music from 1968, returning to Indonesia in 1995. See also http://id.wikipedia.org/wiki/Amir_Pasaribu (accessed 10-1-2011).

19 Concerning Pramoedya Ananta Toer's membership in LEKRA, this is still controversial. There are some who maintain that Pramoedya Ananta Toer was not a member of LEKRA. However, a source that I obtained records Pramoedya's name as a member of LEKRA's Central leadership following the LEKRA National Congress of 24-29 January 1959 in Solo, Central Java. He is also recorded as occupying the position of Director of one of LEKRA's creative institutes, the Indonesian Literary Institute (LESTRA). See 'Lekra Pusat Bentuk Lembaga2', Harian Rakjat, 5-4-1959.

20 The writer Rivai Apin (1927-1995) was, together with A.S. Dharta, editor of the LEKRA journal Madjalah Djaman Baru when it began in 1950. He was later, at various times, on the editorial staff of Gema Suasana, Siasat and Zenith. From 1959-1965 he was on the Central Committee of LEKRA. He was arrested and imprisoned after the 1965 coup and released in 1979. According to Permadi Liosta (painter and member of LEKRA in Bali who was imprisoned on Buru Island), Rivai Apin was also held on Buru.

21 The painter and set designer Basuki Resobowo (1917-1999) was a founder of the 'People's Painters' group (Pelukis Rakjat) in 1947, and one of the founders of the National Film Company (Perusahan Film Nasional, Perfini) together with Usmar Ismail. He was a member of LEKRA's Central Secretariat. After 1965, he lived in exile abroad and died in Amsterdam. See further David Hill 1993.

22 See further 'Jika Amir mengritik Hollywood', http://majalah.tempointeraktif.com (9-22009), (accessed on 1-11-2009). My thanks to Els Bogaerts who informed me about this source. The extent to which LEKRA was a partner of the government in cultural activities in those years still requires investigation.

23 Wienaktoe 1960:19. By 'people's music', Wienaktoe means regional music. 
talization that LMI undertook constituted an effort to find revolutionary forms and music. ${ }^{24}$

Regional music, LEKRA's Secretary Joebaar Ajoeb said in 1964, 'must be developed creatively as the basis for national music. We must develop regional music into a revolutionary music $[\ldots]{ }^{2}{ }^{25}$ In other words, hastening the development of national music required a process of acculturation with society, its structure, and the social ideals of its leaders and quality of its authorities, together with the simplification and improvement of regional music. According to Joebaar Ajoeb, national music would be of no value if it did not include the variety of regional music.

LEKRA also aimed for regional music to achieve the highest prestige within the arena of Indonesian music. This drove LEKRA's efforts to develop regional music into a 'revolutionary' form. Regional music, as a creative product, was to be given revolutionary themes. Its image would then be raised through the organization of regional, national, and revolutionary music festivals and choral competitions.

DEVELOPING REGIONAL MUSIC

One method undertaken by LMI members to develop regional music with a revolutionary character was to change the lyrics or words, that is, to create words that fitted with the reality of the times, without altering the melody. Songs could be popularized (disseminated widely) through their melodies. Yet here Wienaktoe worried that if this was not done carefully, popularized regional music could be trapped as merely entertaining songs that emphasized only their power of attraction, while their actual regional thematic content (substance) would be hidden (Wienaktoe 1960:19).

F.L. Risakotta (1933-?), a poet from Medan and member of LEKRA, discussed the problem of creating songs with melodies from regional music in a lecture he gave to artists of the Satu Nusa Ensemble during a survey visit to West Sumatra in 1964. He took this opportunity to emphasize the need to create new Minang songs such as Kana djo kampuang. Risakotta saw that it was necessary to create rhythms from saluang (bamboo flute) songs, rhythms that were unique to that region. Local artists, by integrating their work

24 According to Busjari Latif, a member of LEKRA, revolutionary music comprises songs that stoke the fires of the People's opposition to oppression. It gives rise to the desire to resist, to wipe away the sorrows of the struggle and give birth to the smile of death. See Busjari Latif 1964. 25 '[h]arus dikembangkan setjara kreatif sebagai basis untuk musik nasional. Musik daerah harus dikembangkan mendjadi musik revolusioner [...]'. See 'Joebaar Ajoeb pada Konfernas I Lembaga Musik; Kembangkan musik daerah untuk basis musik nasional', Harian Rakjat, 4-11-1964. 
with those unique rhythms, could create songs that would be sung for years to come. On the other hand, songs that were mixed with calypso rhythms 'made in USA', he said, would quickly be forgotten. ${ }^{26}$ The story of the composer and musician Michael Karatem (b. 1929) also illustrates the rising awareness of regional music during that era. In 1964 he arranged a song based upon a poem by Putu Oka Sukanta entitled Dikaki-kaki Tangkuban Perahu (In the Tangkuban Perahu foothills) using characteristically Sundanese rhythms. ${ }^{27}$

Renowned composers were also influenced by the current of 'regional music' of the times. Amir Pasaribu, for example, attempted to elevate a Sumatran regional song in a form that was simple and easily remembered, with the title Slamat, slamat (Long live!). This song was sung in two languages - Indonesian and Batak - with the same meaning. 'Slamat' in Indonesian has the same meaning as 'Horas' in Batak. The first refrain of the lyrics uses the word 'slamat' and the second refrain uses 'Horas'. ${ }^{28}$

THE MUSICAL LINE DIVIDING FRIEND FROM FOE

In the early years following the founding of LMI, its attention was primarily devoted to the search for a 'revolutionary' national music. In 1959, Soekarno called on all artists to stand in the ranks of the anti-colonial and anti-imperialist front. In the field of culture, Soekarno campaigned to develop a culture with a national character that rejected imperialist culture. As LEKRA's creative institute in the field of music, LMI followed the Soekarno government's position. ${ }^{29}$ At that time, both the government and LEKRA

26 'Gunakan irama saluang untuk lagu2 Minang', Harian Rakjat, 20-9-1964.

27 Putu Oka Sukanta (b. 1939) is a writer originally from Bali who was formerly a member of LEKRA. He was arrested after the coup in October 1965 and held without trial until 1976. During my research for this essay, I came across Karatem's arrangement of the score for the song Dikaki-kaki Tangkuban Perahu. In 1967, this song became a required number for baritones competing in the annual Radio Star competition, at a time when Karatem and Putu Oka were both in prison. Dikaki-kaki tangkuban Perahu also constitutes a reflection of the cooperation between a poet and a musician. Thanks to Karatem, Titik, and Putu Oka for information on this song.

28 'Slamat, slamat', Harian Rakjat, 20-10-1961.

29 On anti-neo-colonialism/imperialism, see Soekarno's speech of 1963 titled 'Ganjang mereka-mereka jang anti-Nasakom' ('Smash all those who are anti-Nasakom'), the text of which was published in Harian Rakjat, 18-2-1963. Here it is important to note that four years prior to this, President Soekarno called on four ministers to guarantee the security of national culture. These four, the Vice-Ministers of Information, PPDK, Trade, and Minister Ex-Official [sic] of the Police, were to ensure national culture was in harmony with Manipol as well as protecting it from the eroding effect of foreign culture. See 'Presiden panggil 4 menteri untuk mendjamin kebudajaan nasional', Harian Rakjat, 13-8-1959. 
(including LMI within LEKRA) regarded pop culture, especially American pop culture, as imperialist and 'decadent' culture. The most obvious example was in the area of film; but the same was true of music. ${ }^{30}$ Although popular western songs were still played, in 1963 exception was taken to several kinds of songs that were considered 'whiny' (cengeng), like rock 'n' roll.

The statement of Sudharnoto (Chair of LMI) at the LMI Conference in 1964 provides a picture of LMI's stance on Indonesia's musical stage in the midst of a heating political atmosphere. From his statement we can map those considered to be cultural 'foes'.

We must be more vigilant, more tenacious, and more persevering in opposing imperialist culture, especially US imperialist culture, which in reality continues to threaten us in every shape and way. Crazy songs and whiny songs have appeared these days as a result of the vicious attacks of American imperialist culture in the form of reproducing the 'dive-rhythm-music' ala Elvys Presley and 'sex dream' songs ala Tommy Sands. They spread this decadent musical bait in step with their attacks on our People in politics, the economy, and in step as well with their press that immorally desires to tarnish the good name/character of our Great Leader of the Revolution, Bung Karno [...] $]^{31}$

It is clear that anything with a whiff of 'imperialism' or pop à la Elvis Presley was placed in the category of cultural foe. Sudharnoto saw this policy as good practice in line with the teaching of Bung Karno in 'Manipol'-izing Indonesian music. On 14 December 1963 at the Presidential Palace in Bogor, President Soekarno called on artists to present songs in harmony with the 'national character' and suggested that they no longer sing songs

30 See 'Aksi boikot film AS didukung oleh importir film nasional dan OPS Bioskop', Harian Rakjat, 10-5-1964. Further on the film boycotts, see Krishna Sen 1985.

31 Kita harus lebih waspada, lebih ulet, dan lebih gigih melawan kebudajaan imperialis, terutama imperialis AS, jang dalam kenjataan masih terus-menerus mengantjam kita, dengan segala bentuk dan tjaranja. Timbulah lagu2 jang kegila-gilaan dan lagu2 tjengeng dewasa ini adalah akibat serangan djahat kebudajaan imperialis AS dalam bentuk mendjalankan lagu2 'dive-rythm-music' ala Elvys Presley dan lagu2, 'sex dream' ala Tommy Sands. Umpanan2 musik dekaden mereka sebarkan sedjalan dengan serangan2 terhadap Rakjat kita di bidang politik, ekonomi, sedjadjar djuga dengan pers mereka setjara imoral hendak mendjatuhkan nama/ baik pribadi Pimpinan Besar Revolusi kita Bung Karno [...]. 'Ganjang kebudajaan imperialis AS \& Manikebu; Bina musik jang berkepribadian nasional, Pokok-pokok laporan umum ketika lembaga musik Lembaga Musik Indonesia To kepada Konfernas Musik Indonesia', Harian Rakjat, 15-11-1964. 
that weakened the revolution: 'so that the romantic and dynamic of our Revolution truly resound, and don't sing those ngak ngik ngok (rock 'n' roll) songs any more, or Manikebu songs, or sappy songs. ${ }^{32}$

In reaction to what it saw as the increasing dissemination of imperialist songs, the Central Secretariat (Pimpinan Pusat) of LEKRA joined the call for cultural, political, and administrative steps to prevent the spread of 'ngak-ngik-ngok' music, rock 'n' roll (including Indonesian rock 'n' roll like the group Koes Plus), the twist and the Beatles, along with Indian songs regarded as whiny romanticism. ${ }^{33}$ LEKRA's central leadership joined in the campaign against the sale, reproduction of recordings, as well as the imitation of types of music considered decadent. ${ }^{34}$

If LMI regarded pop music (or Indonesian music that imitated foreign pop) as the 'foe', it regarded music with a national character and that firmly maintained a progressive and revolutionary outlook as its 'friend'. Even keroncong music, popular as the music of the independence struggle and well known for its romantic and sentimental style, could be given a progressive and revolutionary identity once its lyrics had been 'revitalized', as was the case with Kroncong Kemajoran, which retained the traditional riddle-like form of verse known as pantun:

Telor pindang mahal harganja

Pelopor pedjuang rakjat pekerdja

Buah nanas mahal di bajar

Meskipun ganas (imperialis dan feudal)

Kita tak gentar

Beli ontjom dipasar minggu

Dengan NASAKOM bersatu.
Chillied eggs are expensive

The workers pioneer the struggle Pineapple costs dearly

Although ferocious (imperialists and feudalists)

We won't tremble

Buy soy cakes at Sunday market

With NASAKOM we unite..$^{35}$

But the case of keroncong was an exception. In general, the music supported as revolutionary consisted of new creations with realistic lyrics emphasizing socio-political conditions and responding to Soekarno's slogans in the form of song.

\footnotetext{
32 '[s] upaja romantic dan dinamik Revolusi kita benar2 berdentam dan tak lagi menjanjikan lagu2 jang ngak ngik ngok, lagu2 Manikebu, lagu2 jang klemek2'. 'Ganjang kebudajaan imperialis AS \& Manikebu, Bina musik jang berkepribadian nasional [...]', Harian Rakjat, 15-11-1964.

33 For more on the anti-Beatles and Koes Plus campaign see Steven Farram 2007.

34 'Ambil tindakan hukum terhadap penjebar musik kontra-revolusioner', Harian Rakjat, 11-71965 .

35 'Kroncong massal Tavip', Harian Rakjat, 20-12-64.
} 
In addition to becoming a political language used to combat one's opponents who were assumed to endanger the national character, leftist music in Indonesia also became a language of solidarity and diplomacy during the 1950s and 1960s. Many songs were created with themes recalling solidarity or took shape as an active response to events that occurred in friendly nations.

The creation of songs with ideological themes constituted one cultural activity strongly supported by socialist countries and the socialist movement in the 1950 s and 1960 s. Socialism was an international movement. It is not surprising then, that Indonesia also created songs that wove together solidarity and stressed bonds between socialist countries (or within the socialist movement).

Not only did songs serve as weapons to strike out at enemies of the Revolution, but they were also at the forefront of diplomacy between countries undergoing similar trials and tribulations. One example is a song from 1946 recalling an event that occurred a year after Soekarno and Hatta had proclaimed Indonesian Independence. This was Indonesia's decision to send rice to India as a fellow country struggling for its independence. The lyrics for the song, entitled Padi untuk India (Rice for India) retold the statement of solidarity when Indonesia's export of 15,000 bales of rice to India was nearly prevented by the Dutch naval blockade. A. Alie turned this event into a song with the following lyrics: ${ }^{36}$

Padi untuk India, djandji dari

pemerintah Indonesia

Padi untuk India, kita rakjat

masih terus berusaha

Padi untuk India, ajo kerahkan

tenaga kita

Memenuhi djandji Negara

Padi untuk saudara India

Padi untuk India, dengan dasar

kemanusiaan kita

Padi untuk India, tolong-

menolong hakikat manusia

Padi untuk India, berkat usaha rakjat semua
Rice for India, promised by

Indonesia's government

Rice for India, our people are

still striving

Rice for India, let's all summon our energy

Fulfilling our country's promise

Rice for brother India

Rice for India, based on our humanity

Rice for India, mutual aid is

fundamentally human

Rice for India, thanks to the work of all the people

36 A score in the private documentation of Mudji Astuti Martoyo (a member of Gembira) bore the title Padi untuk India with A. Alie noted as the creator. I have been unable to trace the identity of A. Alie and the year the song was composed. 
Sekarang telah tersedia padi untuk saudara India.
Now we've sent rice

for brother India. ${ }^{37}$

Music also functioned as a language of solidarity when the Congo's Patrice Lumumba was killed on 17 January 1961. Njoto, one of the founders of LEKRA and at this time a member of its Central Secretariat, later responded to that event in a poem entitled Merah kesumba (Scarlet red). ${ }^{38}$ The composer Amir Pasaribu then adapted the poem as a song. These are the lyrics of Njoto's Merah kesumba:

Darah Lumumba merah kesumba

Darah Lumumba merah kesumba Konggo!

Laparmu lapar kami

Laparmu lapar kita

Lapar revolusi

Darah Lumumba merah kesumba

Darah Lumumba merah kesumba

Konggo!

Revolusimu revolusi kami

Revolusimu revolusi kita

Revolusi dunia. (Njoto 1961.)
Lumumba's blood is scarlet red

Lumumba's blood is scarlet red

Congo!

Your hunger is our hunger

Your hunger is our shared hunger

The hunger of revolution

Lumumba's blood is scarlet red

Lumumba's blood is scarlet red

Congo!

Your revolution is our revolution

Your revolution is our shared revolution

The global revolution. ${ }^{39}$

Music could also be a song of friendship, as was common with state visits, such as foreign heads of state to Indonesia, or of Indonesia abroad. For example, a song was composed to represent the friendship of Soekarno and the leader of North Korea, Kim Il Sung. Entitled Soekarno-Kim Il Sung, with lyrics by S.W. Kuntjahjo and arranged by M. Karatem, the song was created for the visit by Kim Il Sung to the Istana Negara (Presidential Palace) as a guest of state on 10 April, $1965 .{ }^{40}$

37 The lyrics are taken from a recording of the song in the personal documentation of Mudji Astuti Martoyo. This was the product of a recording made by KITLV in collaboration with Suara Pelangi, 2009. Arrangement and lyrics for Padi untuk India by A. Alie, are according to the score found in the private documentation of a member of Gembira.

38 LEKRA, which was sympathetic to the struggle of Lumumba against the imperialists, published a collection of poetry We all are Lumumba that was referred to the Emergency Meeting of the Asia-Africa Writers in Tokyo (1961) and the Meeting of the Board of Solidarity in Bandung (1961). See Laporan kebudajaan (n.d.:120), published by the LEKRA Publications section.

39 Joebaar Ajoeb gives this song as an example of music with a revolutionary spirit along with the song Afrika bersatu (Africa unite) by Sudharnoto and Nasakom by Soebronto K. Admodjo. See Joebaar Ajoeb n.d.:83.

40 See 'Soekarno-Kim Il Sung', Harian Rakjat, 10-4-1965. 
Songs of friendship were also composed for cultural visits, for instance the visit of (North) Korean artists to Indonesia who performed at the Serikat Buruh Kereta Api (SBKA, Railway Workers Union) building in 1963. According to the rapturous report in Harian Rakjat, the building was packed full with the crowd overflowing into the street and the applause was thunderous. Shortly thereafter, the Music and Dance Ensemble Pyongyang sang the songs Kim Il Sung Jang Goon Eunorai, Halo-halo Bandung, Awas Inggris dan Amerika (Beware England and America) and Nasakom Bersatu (Nasakom Unite). Sumardjo of the IndonesiaKorea Friendship Institute opened the program by stating that the event was intended to give form to anti-imperialist solidarity. 'Kim Il Sung and the presence of the delegation of Korean artists demonstrate the intimacy of the friendship between RIRRDK (The Republic of Indonesia and The People's Democratic Republic of Korea), and inspire opposition to U.S.-led imperialism', Sumardjo said. ${ }^{41}$ The visit of the Korean artists along with the coverage of the performance in the (leftist) newspaper in Indonesia indicates the extent to which socialist ideological songs from Indonesia had entered the international socialist repertoire in those times.

Both LEKRA and the government undertook visits and cultural missions of this kind. One resolution of LEKRA's first congress in Solo in 1959 was to organize visits of Indonesian arts delegations to fraternal countries. ${ }^{42}$ For example, in 1963 LEKRA united representatives of several groups, among them the Gembira Ensemble (Jakarta), ${ }^{43}$ to form a cultural delegation to Vietnam, the People's Republic of China (PRC), and North Korea. As a cultural delegation, this visit also gave its participants the opportunity to increase their perception and knowledge in the field of culture, including music. The leader of the mission on this occasion was Drs. Sunardi from Yogyakarta, a dancer and instructor at Gadjah Mada University. ${ }^{44}$ Among those joining the delegation were well-known singer Effie

41 'Seniman-seniman Korea membawa lagu2 Indonesia', Harian Rakjat, 18-4-1963:3.

42 For comparison, see Jennifer Lindsay's essay in this volume concerning state cultural missions abroad. The artists who went on such missions were also impressed with art schools in the PRC.

43 Participants from the Gembira Ensemble were Yulmi, Sulistyaningtyas, Ani Munadi, Kondar Sibarani, and Supardjo (a member of the Pemuda Rakjat or People's Youth). See Koesalah Soebagyo Toer (1998:114) Lampiran 5 'Muhammad Sutiyoso'.

44 Sunardi was a graduate in education (pedagogy) and a classical Javanese dancer. He was the first head (Sekretaris) of LEKRA in Yogyakarta, from 1951. After the 1965 coup he was arrested and held in Wirogunan prison (Yogyakarta) and died. I have not yet found accurate data regarding the years of his incarceration, the time and cause of his death. For further information on the names of participants in this delegation, see BSD 1964. 
Tjoa (classical music vocalist), ${ }^{45}$ Andi Mulia (a classical music vocalist from Makassar), Achmad (violin player), and Muchtar Embut (pianist) who was famous as a composer of songs. ${ }^{46}$ In 2009 I had the opportunity to meet with Michael Karatem, a member of one of the groups that joined the LEKRA delegation in 1963. According to him, the visit to the Hanoi City Hall made a great impression. After the performance had concluded, he recalled, there were no more official ceremonies because the Mayor of Hanoi remarked that 'Soekarno's children are the very nephews and nieces of Uncle Ho himself'. The Mayor then offered his greetings and kissed the delegates while entrusting them with his greetings for President Soekarno. ${ }^{47}$ Karatem also found a visit to a music school in the PRC interesting. He was surprised that China, renowned as a communist country, had a great appreciation of Western classical music. He was even more surprised that Chinese musicians were able to play Indonesian songs most skilfully. He acknowledged that one thing he learned from China was their way of creating music. He explained that he still practices the Chinese method of creating music, for example, in his technique of creating music together with others, especially in dividing tasks between a composer, writer, and linguist.

THE CREATION OF MANIPOL AND TAVIP SONGS

The songs LEKRA supported had to demonstrate themes that were close to reality and to human problems. Music had to contribute to management of the nation, politics, the party, Asian-African solidarity, peasants, and it should not betray the people. These songs generally used a 'march' rhythm, were patriotic and spirited, and encouraged people to manifest the ideals portrayed in the lyrics. The extent of political nuance in the music that LEKRA supported can be seen, for example, in the following lyrics:

45 Effie Tjoa was a famous soprano who was also known as a composer of classical songs (seri$o s a$ ). She was a member of several state cultural missions abroad (see Jennifer Lindsay in this volume).

46 Muchtar (also spelt Mochtar) Embut was born in Ujung Pandang (Makassar), Sulawesi Selatan in 1934 and died in Bandung in 1973. At five years of age, he could already play piano, and four years later composed a children's song entitled Kupu-kupu (Butterflies). At 16 he finished his first composition for piano. He composed more than 100 songs. Several of them are: Di wajahmu kulihat bulan (I see the moon in your face), Di sudut bibirmu (Close to your lips) and Tiada bulan di wajah rawan (There is no moonlight in a troubled face).

47 This story apparently made quite an impression among members of the delegation, as was evident when I read 'Djakarta, Peking, Hanoi, Pyongyang bersekolah dalam missi kesenian Lekra', Harian Rakjat, 16-8-1964. Another member of the delegation told a similar story. 
1 .

Kau tjabut segala dariku tjemar dan noda gelap dan...

Kau beri segala padaku kasih dan bintang-bintang surga

Partaiku, Partaiku segenap hatiku bagimu

Partaiku, kuwarisi api djuangmu

PKI, PKI segenap hatiku bagimu PKI,

PKI, PKI kuteruskan djedjak djuangmu PKI...

You cleansed me of all filth and disgrace...

You gave me everything love and the heavens above

My Party, My Party my whole heart is yours

My Party, I've inherited your fighting flame

PKI my whole heart is yours

PKI I'm following your path of struggle...

(Pudjaan kepada Partai [Worship for the Party], lyrics by S.W. Kuntjahjo ${ }^{48}$

2.

Bulat semangat tekad kita

Barisan sukarelawan Indonesia

Bedil dan sangkur siap bertempur

Siap tantang kita lawan pantang mundur

Hai, hajolah Kawan!

Buruh, tani, pemuda dan angkatan

kita

Madju berlawan siap sendjata dan

tjukupkan sandang pangan

pastilah menang, pastilah menang!

Pasti menang Revolusi Empat Lima

hajolah

Awas imperialisme durhaka

Pasukan Rakjat kita

Kuat perkasa

Ini dadaku

Mana dadau

Kamu menjerang kita ganjang

djadilah...serbu!

Hajolah kawan! Buruh tani...
Our spirit and determination are ripe

Ranks of the Indonesian volunteers

Our rifles and bayonets are ready to fight

Ready to challenge, we oppose, no retreat

Hey, come on friend!

Workers, peasants, youth and our peers

Advance resist weapons at the ready with food and clothing we're sure to win, sure to win! The ' 45 Revolution is sure to win, come on

Look out evil imperialism

Our People's troops

Are strong and brave

Here I am

I dare you to fight

You attack and we will

smash...attack!

Come on friends! Workers peas ants...

(Madju sukarelawan [Advance volunteers], lyrics by Sudharnoto) $)^{49}$

49 Harian Rakjat, 22-3-1964. 
3.

Satu hati satu pikiran

Rakjat Asia dan Afrika

Kita lawan kita kikis penindas dan pendjadjahan

Kita bangkitkan semangat berlawan untuk kemerdekaan

Hidup abadi

Setia kawan Asia dan Africa.
One heart one mind

The peoples of Asia and Africa

We resist we erode oppressors and colonization

We arouse the spirit to resist

for freedom

May it live forever

Solidarity between Asia and Africa.

(Solidaritas Asia Afrika, Kondar Sibarani) $^{50}$

The artists involved with the creation of 'progressive music' in the 1950 s and early 1960s came from a variety of organizations, regions, educational backgrounds, fields of work, and musical experience. Not all of them were LEKRA members. ${ }^{51}$ Sudharnoto (1925-2000) for instance, was an experienced composer. Initially, he studied medicine at the University of Indonesia. Given his musical talent, he switched to a musical career. He is noted as the Vice-General Secretary II (Wakil Sekretaris Umum II), was made manager of LEKRA's Central Secretariat at the first plenary meeting in Solo, Central Java, on 28 January 1959, and was the Chair of LMI (1964). He also worked at Radio Republik Indonesia (RRI, Indonesian National Radio). ${ }^{52}$

Another example is Soebronto K. Atmodjo (1929-1982), born in Pati, Central Java. He honed his musical talent after joining the Gembira Ensemble in February 1952. ${ }^{53}$ According to Titik Kamariah: 'Every time Bung Karno conveyed a statement to society, he (Soebronto) created a song', like Nasakom bersatu (Nasakom unite), Resopim and others. Soebronto worked (1951-1954) as an official in the Department of Education, Training and Culture. He also wrote for the mass media and became the editor of Pemuda (Youth) magazine. ${ }^{54}$ Indeed, in the beginning he had no formal educational training in music. Nevertheless, in August 1965 he finished his stud-

50 Harian Rakjat, 11-4-1964.

51 Mudji Astuti kindly provided the data on the composers Sudharnoto, Soebronto Atmodjo and Kondar Sibarani.

52 After the coup in 1965, Sudharnoto was briefly arrested, but not imprisoned.

53 Thanks to Titik Kamariah (after marrying Soebronto K. Atmodjo she was better known as Titik Soebronto) who provided this information.

54 From 1954 to 1960 Soebronto worked as chief of the secretariat, and translator for the Czechoslovakian embassy in Jakarta. He also assisted with the arts broadcasts of RRI and was in charge of the monthly radio broadcasts of the Gembira Chorus (1954-1961). From 1961-1966 he worked as cultural administrator (rank E/II) in the Inspectorate of Culture for the Jakarta Region under the division of the DPPK. 
ies and graduated 'cum laude' at the Hanns Eisler Advanced Music School, Department of Choral Music and Art Ensembles, in (East) Berlin, the German Democratic Republic. He undertook studies there as an assignment from the Department DPPK. He was also the head of the arts section in the Youth/Students delegation at the 1957 World Festival of Democratic Youth and Students in Moscow. ${ }^{55}$

Kondar Sibarani (1935-2010), creator of the song Solidaritas Asia Afrika, came from Tapanuli, North Sumatra. In Medan he became leader of the Madju Tak Gentar (Fearless Advance) Ensemble. After moving to Jakarta, he also became leader of the Gembira Ensemble. ${ }^{56}$

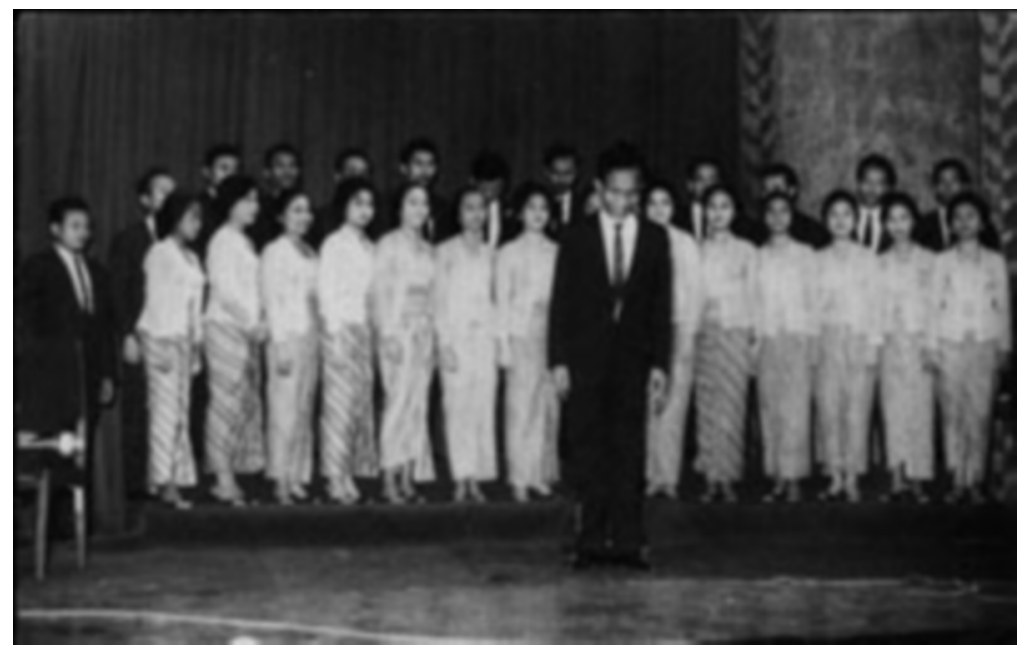

Gembira Ensemble performing at the Gedung Kesenian, Jakarta (date unknown). Kondar Sibarani, conductor.

Female singers, from left to right: Widati, unknown, Yuni, unknown, Sutriningtyas, Sulistyowati, unknown, unknown, Wien, unknown, Meta, Nanik, unknown, unknown.

Male singers from left to right: Supardjo, unknown, unknown, unknown,

Susetyo Toer (Koesalah Toer's younger brother), Rusdianto, Teguh, Bhadri, Sri Malik.

(collection of Yuni. Informants, Mudji Astuti dan Amiyati)

55 Thanks to Titik Kamariah who provided this information in a personal interview, 17-3-2010. Soebronto was arrested briefly in October 1965, then rearrested in 1968 and held without trial, including seven years on Buru Island, until 1977.

56 In 1964 Sibarani went to Beijing, and after the 1965 coup was unable to return to Indonesia. He lived in exile, living finally in Germany where he died in 2010. 
Michael Karatem was born in Ambon in 1929. From a young age he was familiar with Western music, which he studied in school. He joined LEKRA in 1963, and as mentioned above, was a member of the LEKRA arts delegation to Vietnam, the PRC, and North Korea, which acquainted him with the Gembira Ensemble. He worked as a teacher in a People's School in Jakarta. ${ }^{57}$

S.W. Kuntjahjo (1928-?), the writer of the lyrics for Pudjaan kepada Partai (Worship for the Party), was a poet originally from Madura. ${ }^{58} \mathrm{He}$ was active in The All-Indonesia Central Workers Union (SOBSI). The song Pudjaan kepada Partai was given musical arrangement by Subakat. ${ }^{59}$

\section{ENSEMBLES GENERATE A NATIONAL MUSIC}

LEKRA's support for generating a 'revolutionary national music' was directed not only at creating music, but also, as explained above, towards music as an activity, especially as an activity of youth and students. The period from the late 1950s to the early 1960s was a fertile one for song ensembles, or music and dance ensembles, which performed a repertoire of new 'progressive' or 'revolutionary' creations, along with national songs and regional songs with new arrangements (in the style of Western diatonic music). Choral singing constituted an enormously popular activity in socialist countries during this era. It aimed to build solidarity among youth, and was supported by world youth festivals and meetings, exemplified in the World Festival of Youth and Students that the World Federation of Democratic Youth organized every two years. In Indonesia, the emergence of ensembles was influenced and inspired by this. However, these ensembles also developed from a local context, that is, as a kind of search for a 'national music'.

LEKRA gave these ensembles the elevated function as weapons to drive out Western music (meaning pop music), as stated in LEKRA's plenary report for 1961 delivered by Joebaar Ajoeb,

57 Interview with Karatem in Jakarta, 14-1-2010. Michael Karatem composed many songs such as Gugur ditanah garapan (Death while working on land owned by others), Pemuda nyalakan api Revolusi (Youth ignite the fire of Revolution), and arranged songs including Bunga merah (Red flower), Djangan djamah Tukin (Don't touch Tukin), Ketaon. After the coup of 30 September-1 October 1965, Karatem was arrested and held without trial until 1978, ten of those years (19681978) spent on Buru Island.

58 For more on S.W. (Supii Wishnu) Kuntjahjo, see Michael Bodden in this volume.

59 According to Mudji Astuti Martoyo, Subkat was a nickname coined by Soebronto Kusumo Atmodjo for Muchtar Embut. 
secretary of LEKRA's Central Secretariat: 'Choruses like Gembira, Madju Tak Gentar, Bandung and the RRI Chorus, must be spread, become mass phenomena, so that we can find a basis for improvement, so that we are able to defeat the dreadful influence of those rotten foreign musics'. ${ }^{60}$

In the 1950s and early 1960s, music and dance ensembles appeared in various regions according to differing initiatives and desires. The Gembira Ensemble, for example, was established in Jakarta at the initiative of youth who were sent to the World Festival of Youth and Students in Berlin in 1951. Madju Tak Gentar was formed at the end of 1959 in Medan. The idea for the founding of Madju Tak Gentar arose from the initiative of members of the state sponsored Sumatran arts mission, headed by the Medanbased writer Banda Harahap (aka Hr. Bandaharo), which toured to the PRC, North Korea, and the Democratic Republic of Vietnam in 1959. The idea was crystallized during the journey home on the ship Tjiwangi. ${ }^{61}$ In Yogyakarta, the music and dance ensemble Bhineka appeared. The membership of this ensemble, formed in December 1963, was Indonesian-Chinese. Harian Rakjat reported its guiding principle was to confirm 'art for the people' (seni untuk rakyat), and its concrete action was to join in 'crushing' ngakngik-ngok music, the twist, and the like (Kusni Sulang 1964). In Pontianak, LEKRA established the Angin Timur (Eastern Wind) Ensemble that aimed to spread revolutionary songs among the people. Harian Rakjat reported that Angin Timur was founded to become a wind from the East that would block the influence of culture that LEKRA regarded as decadent. The members of Angin Timur were artists from various ethnic groups, including Chinese. Thus, as Roeslan wrote in Harian Rakjat, it could be said that Angin Timur was LEKRA's 'unity in diversity' (bhinneka tunggal ika) to lay the foundation for a revolutionary cultural front, recalling that the population of West Kalimantan was composed of various ethnic groups including Dayak, Malay, Javanese, Madurese, Tapanuli and Chinese (Roeslan 1964).

The mobility of these ensembles was an important factor in assuring their popularity. The Bhineka Ensemble from Yogyakarta, for example, was able to present a series of performances in regions such as Kediri, Klaten, Solo, and even outside of Java, in Lampung

60 'Paduan2 suara seperti, "Gembira”, "Madju Tak Gentar", "Bandung” dan "Paduan Suara RII”, harus diluaskan, dimassalkan, sehingga menemukan basis perkembangannja untuk meninggi, sehingga mampu mengalahkan pengaruh buruk musik2 asing jang busuk itu' (Joebaar Ajoeb n.d.:91). Joebaar Ajoeb (2004:113) states that the Gembira and Madju Tak Gentar Ensembles were just two of many dozens of such ensembles that paid attention to regional music.

61 'Madju Tak Gentar pemegang piagam Widjajakusuma', Harian Rakjat, 17-1-1965. 
(Kusni 2007:29). One indication of their popularity was the fact that the ensembles performed not only for the Left. For example, as part of its artistic activity the Angin Timur Ensemble also entertained Indonesian troops on the front lines during the confrontation with Malaysia, as well as volunteers in Pontianak (Roeslan 1964).

According to Joebaar Ajoeb in his General Report to LEKRA's first congress (1959), the duty of the ensembles was to revive people's art from the oppression of (domestic) feudalism and (foreign) imperialism. He explained that what he meant by 'revive' was 'not in a negative sense of simply preventing people's art from dying out, but rather to revive it in a positive sense, especially by 'giving it new content that matches the character and aims of the August Revolution'. ${ }^{62}$

Each ensemble had its own unique connection with LMI and LEKRA, both as an institution and on the part of individual members. The Gembira Ensemble, for instance, was not institutionally a part of LEKRA, but several of its managers and founders were members of LEKRA (like Sudharnoto), and some were even members of the Communist Party (for example, Bintang Suradi) ${ }^{63}$ Still, not all of Gembira's members were members of LEKRA, even though LEKRA praised it as a model, citing the Gembira Ensemble in its plenary meetings as a chorus whose membership could appropriately be broadened and whose activities could be spread to the masses in order to drive out Western (popular) music. But at the same time, Gembira was also the ensemble the government most frequently invited to perform for state functions, such as welcoming foreign dignitaries. ${ }^{64}$

62 This statement implied that the work of a researcher or musicologist was equivalent to the cultural activity of LEKRA as far as striving to document, gather, then study and map out the musical realities within their socio-cultural context was concerned. See the General Report of the LEKRA's Central Secretariat in the 1st Congress at Solo which was published in full in Harian Rakjat, 31-1-1959.

63 Bintang Suradi's original name was Van de Ster (Ster in Dutch, means star or bintang). Thanks to Mudji Astuti, a member of Gembira, for this information. Bintang Suradi was born of Dutch and Indonesian parents in Malang in 1923. In addition to being one of Gembira's founders, Bintang Suradi joined various activities and organizations. He was Secretary of the Organisasi Indonesia untuk Setiakawanan Rakjat Asia-Afrika (OISRAA, Indonesian Organization for Solidarity with the Peoples of Asia-Africa), and he was also noted as the personal secretary for D.N. Aidit, Chairman of the PKI's Central Committee. Bintang died in his 40s, from drowning as he swam at Pelabuhan Ratu on Saturday 22 June 1963. See 'Bintang Suradi', Harian Rakjat, 24-6-1963.

64 According to the explanation of Hardiani (Nanik) and Sulistiangsih (Lies) - both members of Gembira who joined the delegation to Vietnam, China, and North Korea in 1963 - in addition to performing at the Istana Negara (Presidential Palace) in Jakarta, they also frequently performed at the Bogor Palace (interview, 7-9-2009). 
To better understand the activities and membership of the music ensembles, and the complexity of their relations with the government, the Left political movement, socialist ideology, and even with the PKI itself, I will now take the Gembira Ensemble as an example.

In a meeting in the Kalibata area of Jakarta in 2009, a grandmother told of her journey 48 years before. She was Titik Kamariah, the one woman who participated in founding the Gembira Ensemble. ${ }^{65}$ Her story is as follows:

\begin{abstract}
Back in the Old Order days, there were democratic youth and students who were sent to Europe (East Germany). That European nation organized a festival. The program inspired us about people's arts, which were featured prominently. When we returned home in February, Bintang Suradi and Sudharnoto joined our group. We sat down together and decided to form a seni suara (vocal arts) group (back then they were called paduan suara or choral group). The group had to be given a name, so there was a suggestion for 'Gembira' (glad) as something light. If we sing like that we're happy. So we tinkered with that name until we got the Gembira Chorus. Sudharnoto became the director, Bintang Suradi was the chairman, and I was the secretary ${ }^{66}$
\end{abstract}

As Titik Kamariah's recollections show, the discussions in Jakarta at No. 9 Tegalan Street (where Sudharnoto was lodging at the time) and the birth of the choral group were a direct outcome of the delegation to the 1951 World Festival of Youth and Students in (East) Berlin. ${ }^{67}$. The founding of that chorus was directly inspired

65 Titik Kamariah, born in 1924, was the sole woman who took part in founding the Gembira Ensemble. At the age of 28, in 1951, she was a delegate to the World Festival of Youth and Students in Berlin, as representative of the Socialist Youth.

66 Dulu zaman orde lama ada pemuda-pemuda dan mahasiswa demokratis yang dikirim ke Eropa (Jerman Timur). Negara Eropa itu mengadakan festival. Dari acara itu kita diinspirasi tentang kesenian-kesenian rakyat yang ditonjolkan. Waktu kita pulang bulan Februari, kita bertiga ditambahin Bintang Suradi dan Sudharnoto. Kita duduk bersama dan berinisiatif membentuk kelompok seni suara (dulu namanya paduan suara). Kelompok ini harus dikasih nama, maka waktu itu ada usulan Gembira ringan. Kalau kita nyanyi itukan kita gembira. Jadi diotak-atik itu namanya jadi seni paduan suara Gembira. Yang jadi dirijen Sudharnoto, yang jadi ketua Bintang Suradi, saya sekretarisnya. Excerpt from an interview with Titik Kamariah, Jakarta 10-5-2009.

67 Indonesia sent several youth delegates to the 1951 World Festival of Youth and Students from various fields, including Henk Ngantung who represented the plastic arts. Bintang Suradi was also one member of the delegation. He was living in the Netherlands at the time, and joined the Indonesia representatives at the Festival (interview with Titik Kamariah, Jakarta, 10-5-2009). 
by admiration for the performances from other countries at the Berlin Festival that emphasized people's art. On 3 February 1952 this choral group was formally founded with the name Gembira. ${ }^{68}$ According to Titik Kamariah, while the name Gembira was chosen because it was thought to represent the feeling of happiness when people sing, she explained that Soebronto K. Atmodjo said that although Gembira was a light-sounding name, within the group there was a great feeling of responsibility.

The requirements for becoming a member of Gembira were simple. It was enough to be interested in music and to take a brief vocal test and some elementary musical theory. Sudharnoto usually selected the candidates for membership according to voice type alto, soprano, or tenor. Later, potential members were also required to complete their biodata on a form and submit a personal photograph (at that point around 150 people were registered).

Gembira had to practice in various places because it had no rehearsal space of its own. According to Amiyati, who joined in 1961, Gembira even practiced in the RRI Building. Titik Kamariah remembered that Gembira often rehearsed in the Gedung Pemuda. Yet another member of Gembira, Koesalah Soebagyo Toer, indicated that Kramat Street, Gang Tengah, Kimia Street, and the RRI Building were practice spaces (Koesalah Soebagyo Toer 1998:11).

Gembira relied upon members' dues as the main source of funds for its activities, with additional funds coming from sponsors and donations by the government and particular individuals (Koesalah Soebagyo Toer 1998:25-6). The Government provided periodic support on occasions when Gembira was invited to perform for state ceremonies, such as Independence Day celebrations on 17 August or to welcome guests of state. ${ }^{69}$

In 1955, Gembira changed its name to Ensambel Njanji dan Tari Gembira (Gembira Music and Dance Ensemble).$^{70}$ Despite the name change, its activities were confined to the field of choral music without dance. Choral activities without dance were more emphasized because Gembira had initially been constituted as a chorus (paduan suara). According to Soebronto, the name was changed to Gembira Music and Dance Ensemble to put emphasis on songs of the People.

68 Excerpt from an interview with Titik Kamariah, Jakarta, 10-5-2009. The following information is also from this interview, and supplemented by an interview with Gembira members Mudji Astuti and Amiyati, Jakarta, 20-5-2009.

69 Koesalah Soebagyo Toer 1998:109. Interview with Amiyati 20-5-2009.

70 See Appendix 4 in Koesalah Soebagyo Toer 1998, 'Pidato dasawarsa Pimpinan Umum Ansambel Njanji \& Tari “Gembira” tgl. 3 Februari 1962' (Tenth anniversary speech by the leadership of Gembira Music and Dance Ensemble). 
From the outset, Gembira dedicated itself to participating in the active development of national culture by performing songs imbued with ideas of peace, solidarity, and the love of freedom, themes common to the socialist countries of that era. This stance is recorded in the founding principles of Gembira as expressed by Bintang Suradi:

[t]he principles and aims of Gembira are to defend as well as actively help develop national culture, to implant and deepen feelings of love for our country, love of peace and love for the People of the world, via the form of songs, while introducing the songs of Indonesia and foreign songs that contain love of freedom, solidarity, and peace. ${ }^{71}$

As well as performing songs that followed the beliefs and style of international socialism, the Gembira Ensemble also helped to develop a kind of music considered to be uniquely Indonesian, namely keroncong. Gembira performed new keroncong arrangements and added lyrics, like Iskandar's Bandar Jakarta (Jakarta Harbour) or Keroncong Kemayoran and Jali-jali with arrangements by Sutijoso. ${ }^{72}$ When Gembira participated in the choral competition for the PKI's 45th Anniversary in 1965, the Chairman of the PKI, D.N. Aidit even had words of praise for keroncong (Koesalah Soebagyo Toer 1998:115).

The Gembira Ensemble's repertoire was quite broad, covering socialist songs, popular European music, and Indonesian music. One can get a picture of Gembira's activities from Harian Rakjat's coverage of the performance for closing ceremonies of the Police Force Cadre's School held concurrently with the anniversary of the Ensemble at the Bogor Palace on 19 March 1965. The President and Madame Hartini Soekarno attended this performance, as did the Minister in Command of the Police Force, Sutjipto; the Minister of Information, Achmadi; and foreign military attachés. In addition to keroncong, the songs performed at this celebration included Djamilah, which was an expression of the Indonesian People's sym-

71 [a]zas dan tudjuan Gembira adalah mempertahankan serta turut serta aktif mengembangkan kebudajaan nasional, menanamkan dan memperdalam rasa tjinta tanah-air, tjinta perdamaian dan tjinta kepada Rakjat sedunia, melalui bentuk njanji dan memperkenalkan lagu2 Indonesia dan lagu2 luar negeri jang mengandung isi tjinta kemerdekaan, setiakawan, dan perdamaian (Tjahajani 1965).

72 'Ansambel Gembira di Istana Bogor', Harian Rakjat, 28-3-1965. 
pathy with the Algerian People's struggle, Kim Il Sung Djang Qun, the Chinese song Bom noral, Funiculi funicula, Sajang dilale, Duaenam Djuli, and closed with Halo-halo Bandung performed by Muchtar Embut. ${ }^{73}$

Gembira appeared in a variety of national and international meetings, from the State (Presidential) Palace stage to meetings and receptions for the revolutionary masses. In international meetings, the Ensemble usually had the role of welcoming foreign guests by performing Indonesian songs and songs from the countries being entertained, as, for example, when greeting North Vietnam's 'Uncle Ho', or the Soviet Union's Nikita Krushchev and K.E. Voroshilov (Koesalah Soebagyo Toer 1998). To date, I have found no sources to indicate that Gembira was invited to participate in welcoming guests from non-socialist countries.

According to Harian Rakjat, Gembira's repertoire was known in China, North Vietnam, North Korea, and various Eastern European countries. The song Siap bebaskan Irian Barat (Ready to liberate West Irian) by Soebronto K. Atmodjo, for instance, was sung at the World Festival of Youth and Students in Helsinki, Finland, in 1962 and also recorded by Radio Peking. Similarly, Muchtar Embut's compositions like Dari rimba Kalimantan Utara (From the jungles of North Kalimantan) were recorded during the tour of LEKRA's arts delegation to China, North Korea, and North Vietnam in $1963 .^{74}$

The composer Ma Co from the PRC who attended LEKRA's national conference in February 1964, reported that Soebronto K. Atmodjo had composed the majority of the people's songs for the Gembira Music and Dance Ensemble. ${ }^{75}$ An example of folk music whose 'discovery' was attributed to Soebronto and solicited exclamations of admiration, was the song from Ambon entitled Bila ale kembali (When I return).

In addition to revolutionary and regional songs, Gembira also performed children's songs composed by Ibu Sud, ${ }^{76}$ and it is said that a recording of these songs was made at Irama studio in Cikini Raya Street. This shows that Gembira didn't merely perform the songs or arrangements by its own members. Ibu Sud is known as a popular composer of children's songs; her songs later became stan-

73 'Ansambel Gembira di Istana Bogor', Harian Rakjat, 28-3-1965.

74 See '12 Tahun Gembira; turut mengobarkan api Revolusioner', Harian Rakjat, 16-2-1964.

75 Harian Rakjat, 4-8-1964.

76 Ibu Sud (1908-93) whose full name was Saridjah Niung Soedibjo, was born in Sukabumi. She was renowned as a composer of children's songs, especially in the educational circles of Taman kanak-kanak (kindergartens). She died at the age of 84. 'Ibu Sud', http://wapedia.org (accessed 5-7-2009). 


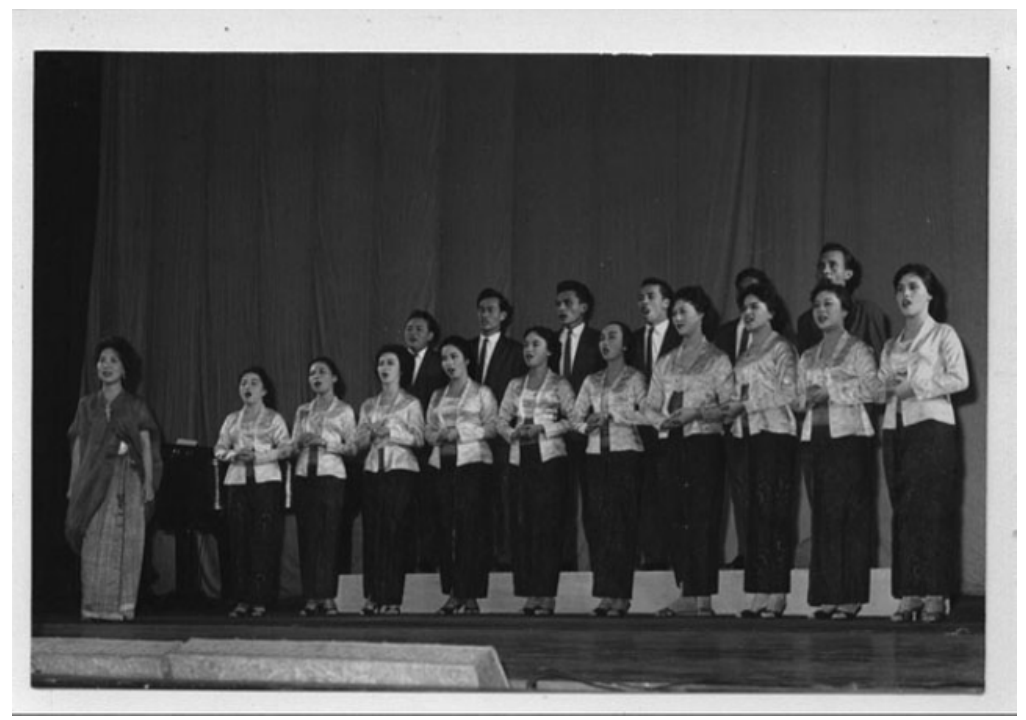

Gembira members with other singers performing in Beijing, 1963 to mark the PRC national day of October 1.

Soloist Effie Choa (left) with, front row, left to right; Atik, Yuni (Gembira), Eveline Chauw, unknown, Amik (Gembira), Lies (Gembira), unknown, Supini (Gembira), Nanik (Gembira), unknown. Back row (males, left to right): Surekto, unknown, Tobing, others unknown. (collection of

Yuni. Informants, Mudji Astuti and Amiyati)

dard fare in kindergarten education up until the 1980s. I myself learned several of her songs, for instance, Menanam jangung (Planting corn), Pergi belajar (Off to study), Nenek moyang (Our ancestors), Kereta apiku (My train), Hai becak (Hey pedicab), Burung kutilang (The bulbul) at kindergarten (1986) and I still remember them well.

FROM STAGE TO STAGE

Above and beyond its status as a vocal ensemble, Gembira was duly acknowledged as an arts and culture organization by the government. Among other things, the government's invitation to the group to attend the 1959 Cultural Congress in Bali proves this point (Koesalah Soebagyo Toer 1998:61). Prior to this, in August 
1953, Gembira also sent a representative to the Fourth World Festival of Youth and Students in Bucharest, Romania. ${ }^{77}$

Gembira participated in the Konfernas Seni dan Sastra Revolusioner (KSSR or Conference on Revolutionary Literature and Art) held in Jakarta from 27 August to 2 September 1964, which was organized by the Communist Party. In May 1965, Gembira, together with the Madju Tak Gentar Ensemble, LEKRA, Ikatan Pemuda Pelajar Indonesia (IPPI, League of Indonesian Youth and Students), Consentrasi Gerakan Mahasiswa Indonesia (CGMI, Indonesian Student Movement Concentration), Pemuda Rakjat (Youth of the People) and Gerakan Wanita Indonesia (Gerwani, Indonesian Women's Movement) also participated in the Indonesian Communist Party's 45th Anniversary which took place over three consecutive nights in the Istana Olaraga Senayan (Istora, Senayan Sports Palace). A performance of dance drama (sendratari) titled Djajalah partai dan negeri (Party and country victorious) added splendour to the festivities. ${ }^{78}$ Sudharnoto and Muchtar Embut were in charge of the music, Basuki Resobowo (a member of LEKRA's Central Secretariat), Atjoen from Permusjawaratan Pemuda Indonesia (PPI, Indonesian Youth Deliberations) and Sujud (a member of the Central Java LEKRA branch and active in dance) arranged the choreography, while the chorus was led by Michael Karatem and Su Tji Tien (Gembira), and Amir Siregar (Madju Tak Gentar). The music and dance drama were created by Muchtar Embut and Sudharnoto. The chorus for the program sang the following songs: 12 November, Selendang sutra (Silk scarf), Di timur matahari mulai bertjahaja (the Eastern sky is brightening), Mars Gerindo, Satu nusa satu bangsa (one archipelago, one people), Nasakom, Djajalah partai dan negeri, and the Internasionale. ${ }^{79}$

According to Mudji Astuti, the celebration of the PKI's anniversary was so grand that the participants in the performance were assembled in a configuration that formed pictures of Soekarno and Aidit (Chairman of the PKI's Central Committee). This configuration, composed of 10,000 students, was organized with the assistance of Korean advisors and was led in rehearsal by Hari Safii (a member of IPPI). ${ }^{80}$ Amir Siregar (a tenor from the Madju Tak Gen-

\footnotetext{
77 Koesalah Soebagyo Toer 1998:106. See Appendix 4, 'Pidato dasawarsa pimpinan umum Ansambel Njanji \& Tari “Gembira” tgl. 3 Februari 1962' in Koesalah Soebagyo Toer 1998. According to Titik Kamariah, Soebronto K. Atmodjo was a member of the delegation.

78 See Michael Bodden's essay in this volume for more information on the performance of Djajalah partai dan negeri.

79 'Sendratari Djajalah Partai, Djajalah Negeri', Harian Rakjat, 30-5-1965.

80 Thanks to Hari Safii whose personal communication included a picture of the staging for that performance.
} 
tar Ensemble) and Emi Aritonang (alto from the Madju Tak Gentar Ensemble) performed solos in this performance. ${ }^{81}$ The singers in the chorus (combining the Gembira and Madju Tak Gentar Ensembles) for the performance numbered approximately $150 .{ }^{82}$

Gembira frequently performed for PKI or LEKRA sponsored events, while also performing in state programs. Because they performed so many times at the State Palace, Gembira was given the nickname 'Palace chorus'. Gembira also often performed for Indonesian National Radio, (Radio Republik Indonesia, RRI) ${ }^{83}$ and was once commissioned to perform by the Timur Bank (a bank owned by the Partai Nasional Indonesia or Indonesian National Party).

\section{CONCLUSION}

This is a brief portrait of one strand of Indonesian music in the late 1950 s and early 1960 s, one that once gave extra colour to the path of Indonesian history. During those times, all sectors of society struggled (and simultaneously competed) to define national identity. Cultural organizations like LEKRA, Lembaga Seniman dan Budayawan Muslimin Indonesia (LESBUMI, Institute of Indonesian Muslim Artists and Cultural Figures), Lembaga Kebudayaan Nasional (LKN, Institute of National Culture) and others arose and took an active role in thinking about and adding lustre to the Indonesian cultural stage in order to shape a national identity. Each separate institute sought, shaped and produced the pattern of 'national culture' according to its own identity. Some had a socialist nuance, some were based upon nationalism, and some were even based on religion. This was in accordance with Soekarno's elaboration of his concept of NASAKOM.

The stage of Indonesian music was a passionate one during the 1950s when concerts, festivals, shows and international-level cultural missions took place. The search for a national identity in the field of music drove LEKRA and LMI activities. Music, in LEKRA's view, had to be socially engaged and take a stand. It was not mere entertainment, but rather had to prompt society to join in attacking

81 Thanks to Mudji Astuti who provided information about Amir Siregar and Emi Aritonang through personal communication, 5-4-2010. On 5 October 1965, Mudji Astuti took Emi Aritonang to the airport to leave for school in Italy with the support of the Soekarno government. 82 Thanks to Mudji Astuti Martoyo and Hari Syafii for detailed descriptions via personal communication on 28-8-2009.

83 It is worth noting that although not discussed at greater length in this paper, RRI (Radio Republik Indonesia) played an important role in the history of Indonesian music. 
the enemies of the Revolution. The song lyrics clearly demonstrate this. In addition, songs were written with lyrics that constituted responses to events occurring in friendly countries undergoing similar trials and tribulations.

LEKRA's activities consisted not only of cataloguing and nurturing music, but also in arming it with revolutionary ideology. For LEKRA, music became a kind of cultural path for international diplomacy, as well as a language of friendship and solidarity, and a way to remember or respond to an event. Music mapped out friends and foes.

The Indonesian musical stage was enlivened by the music and dance ensembles in the 1960s. Choral ensembles became a popular musical activity. Ensembles such as Gembira performed not only for leftist circles, but also took part in entertaining Indonesian troops on the front lines (in the Confrontation with Malaysia). Their flexibility in serving the needs of various circles was one factor that made them quickly gain popularity and acceptance from society as a whole.

The Central Secretariat of LEKRA also held up choral ensembles as an example of musical groups that played a part in fending off dangerous imperialist culture. Choral ensembles were regarded as bearers of music that mirrored national identity. Clearly, national identity here did not mean something pure, excavated intact from local heritage, but rather something that also borrows selectively from the treasury of world music. The socialist network greatly facilitated the opening of channels to the treasury of international music, both ideologically socialist music, and Western classical music.

Finally, how far did choral ensembles shape an identity that could be said to be national? Ultimately, what we might call national identity in music is a hybrid that mirrors a mix of several elements and influences. It was politics, in the sense of a revolutionary and anti-capitalist spirit, that then sifted, selected and discovered what could be called national and what could not.

In line with the drastic change in Indonesia's political situation post-30 September-1 October 1965, the choral ensembles, which became labelled as synonymous with leftist politics, had to leave the stage, leaving almost no trace. Suppose they did not have to bow out, how would ensembles look in the Indonesian music industry today?

Unfortunately, history allows no place for such hypothetical questions.

Translated from Indonesian by Michael Bodden 


\section{REFERENCES}

Aiko Kurasawa

1993

Mobilisasi dan kontrol; Studi tentang perubahan sosial di pedesaan Jawa 1942-1945. Jakarta: Yayasan Karti Sarana, Gramedia Widiasarana Indonesia (Grasindo).

BSD

1964 'Djakarta, Peking, Hanoi, Pyongnyang; Bersekolah dalam missi kesenian Lekra', Harian Rakjat, (16 August).

Eritha Rohana Sitorus

2009

Amir Pasaribu; Komponis, pendidik Ẽ perintis musik klasik Indonesia. Yogyakarta: Media Kreatifa.

Farram, Steven

2007

'Wage war against Beatle music! Censorship and music in Soekarno's Indonesia', Review of Indonesian and Malaysian Affairs 41-2:247-77.

Foulcher, Keith 1986

Social commitment in literature and the arts; The Indonesian 'Institute of People's Culture' 1950-1965. Clayton: Southeast Asian Studies, Monash University. [Monash papers on Southeast Asia 15.]

Hill, David T.

1993

'Basuki Resobowo; Creative energies in exile', Inside Indonesia 36 (September):38-41.

Joebaar Ajoeb

n.d.

“"Luntjurkan anakpanah" kedjantung kebudajaan imperialis laporan umum', in: Laporan Kebudajaan Rakjat II. Djakarta: Penerbitan Lembaga Kebudajaan Rakjat.

2004 Sebuah mocopat kebudayaan Indonesia. Jakarta: Teplok Press.

Koesalah Soebagyo Toer

1998 'Ke langit biru; Kenangan tentang "Gembira”'. [Manuscript.]

Kusni, J.J.

2007

Aku telah dikutuk jadi laut; Surat-surat seorang eksil kepada (seorang) anak muda NU. Yogyakarta: Syarikat.

Kusni Sulang

1964

'Ansambel Bhineka tegak dengan Garis-Politik jang tepat', Harian Rakjat, (2 January).

Laporan Kebudajaan

n.d. Laporan Kebudajaan Rakjat II. Djakarta: Penerbitan Lembaga Kebudajaan Rakjat. 
Manik

1952

'In memoriam; C. Simandjutak', Mimbar Indonesia 39 (27 September):11-3.

Mrázek, Rudolf

1994

Sjahrir; Politics and exile in Indonesia. Ithaca, NY: Southeast Asia Program, Cornell University. [Studies on Southeast Asia 14.]

Njoto

1961 'Merah kesumba', Harian Rakjat, (25 April).

Pramoedya Ananta Toer et al.

1999 Kronik Revolusi Indonesia, Jilid I (1945). Jakarta: Kepustakaan Populer Gramedia.

Rhoma Dwi Aria Yuliantri and Muhidin M. Dahlan (eds)

2008

Lekra tak membakar buku; Suara senyap lembar kebudayaan Harian Rakjat 1950-1965. Yogyakarta: Merakesumba.

Roeslan

1964

'Angin timur kumandhang lagu2 revolusioner', Harian Rakjat, (11 October).

Sen, Krishna

1985

'Hidden from history; Aspects of Indonesian cinema 195565', Review of Indonesian and Malaysian Affairs 19-2 (Summer): $1-55$.

Sudharnoto

1964

'Betapa besar bahaya musik dekaden', Harian Rakjat, (2 November).

1965 'Luaskan paduan suara sampai ke-desa2', Harian Rakjat, (5 September).

Tjahajani

1965

'Suatu dorongan bagi Gembira', Harian Rakjat, (21 February).

Wienaktoe

1960

'Musik berkepribadian melalui musik Rakjat', Mimbar Indonesia 22 (28 May):19. 